\title{
PENGUATAN PENDIDIKAN KARAKTER TANGGUNG JAWAB SEKOLAH DASAR DI ERA PANDEMI
}

\author{
Rivan Gestiardi, Suyitno \\ Universitas Sebelas Maret Surakarta dan Universitas Ahmad Dahlan Yogyakarta \\ Indonesia \\ Email: rivan27@student.uns.ac.id
}

\begin{abstract}
Abstrak: Penguatan Pendidikan Karakter (PPK) adalah upaya untuk membentuk karakter siswa di Indonesia agar menjadi orang yang baik, berguna untuk dirinya dan sekitarnya. Dengan kebijakan daring selama masa pandemi Covid-19, terjadi perubahan proses pendidikan karakter yang berbeda. Tujuan penelitian ini mendeskripsikan penguatan pendidikan karakter tanggung jawab di Sekolah Dasar Muhammadiyah Ngabean I di Yogyakarta di masa pandemi Covid-19. Penelitian ini menggunakan jenis penelitian deskriptif kualitatif dengan desain penelitian studi kasus. Pengumpulan data pada penelitin ini dilakukan dengan teknik observasi, wawancara, dan studi dokumen. Hasil penelitian menyimpulkan penguatan pendidikan karakter tanggung jawab di masa pandemi dilakukan dengan cara: (1) sekolah mengintegrasikan nilai karakter tanggung jawab ke dalam pembelajaran, dan juga dengan cara sekolah menerapkan protokol Kesehatan; (2) SD Muhammadiyah Ngabean 1 memfokuskan program penguatan pendidikan karakter pada nilai tanggung jawab dalam mengerjakan tugas masing-masing yang diberikan oleh guru; dan (3) sekolah berkerja sama dengan orang tua untuk melaksanakan pendidikan karakter tanggung jawab kepada siswa dalam pendampingan pembelajaran selama di rumah.
\end{abstract}

Kata Kunci: penguatan pendidikan karakter (PPK), sekolah dasar, pandemi covid-19

\section{STRENGTHENING THE RESPONSIBILITY CHARACTER EDUCATION OF ELEMENTARY SCHOOLS IN THE PANDEMIC ERA}

\begin{abstract}
Character education is the beginning of efforts to form a character, which is the basis for being useful for himself and his surroundings. This policy, students experience changes and different habits, usually done in schools, is now changing in their respective homes. This research uses descriptive qualitative research design with descriptive case study research design. Data collection in this research is done by using observation, interview, and documentation techniques. This research aims to describe the character strengthening program carried out by elementary schools in Yogyakarta. Strengthening character education of primary schools in a pandemic is carried out by: (1) the role of school in calling for the implementation of health protocols such as using hands frequently using masks and maintaining a safe distance from each other; (2) the school also collaborates with parents to emphasize character education of students in learning assistance while at home; and (3) SD Muhammadiyah Ngabean 1 focuses on strengthening characters, namely discipline and responsibility in doing each assignment given by the teacher.
\end{abstract}

Keywords: strengthening character education, elementary school, pandemic

\section{PENDAHULUAN}

Pendidikan berupaya mengembangkan kemampuan pribadi peserta didik agar dapat berdiri sendiri. Fattah (2016) menjelaskan pendidikan merupakan upaya membimbing anak ke arah sesuatu tujuan yang bernilai besar. Pendidikan yang baik merupakan muara tujuan pendidikan yang sesungguhnya. Pendidikan mempunyai relevansi yang kuat dengan tuntutan serta kebutuhan bangsa Indonesia dalam melahirkan masyarakat yang inovatif, cerdas, dan mempunyai jati diri yang kukuh. Dalam mencapai tuntutan serta kebutuhan bangsa dibutuhkan banyak opsi pendekatan yang lebih bisa memegang esensi nilai 
moralitas dari sesuatu konsep keilmuan di samping pencapaian nilai akademik. Pendidikan hendaknya mampu membagikan peluang penuh kepada peserta didik guna mengeksplorasi serta meningkatkan kepribadian secara optimal dengan senantiasa mencermati berbagai aspek keilmuan.

Pendidikan dianggap sebagai upaya preventif karena pada dasarnya pendidikan membangun generasi baru bangsa yang lebih baik, yang diharapkan dapat memperbaiki kualitas generasi muda (Nasional, 2010). Pendidikan merupakan suatu bentuk usaha secara sadar dan sistematik dalam mengembangkan potensi pesera didik. Biasanya ditandai oleh pewarisan budaya serta karakter yang dimiliki oleh bangsa Indonesia sejak dahulu. Pada perkembangannya, tantangan serta kesempatan pendidikan mengupayakan perbaikan mutu sumber daya manusia sejak usia Sekolah Dasar (SD) ditempatkan pada Program Penguatan Pendidikan Karakter (PPK). Peserta didik mempunyai kemauan serta kebutuhan dasar sehingga dibutuhkan peran beberapa lingkungan primer di sekitarnya. Keefektifan pendidikan karakter ideal ditentukan oleh nilai dasar karakter budaya sekolah, keluarga, dan masyarakat, integrasi program kurikuler dan ekstrakurikuler, teladan pendidik bagi peserta didik, dan penggunaan situasi lingkungan budaya sekolah (Ruyadi, 2010). Moralitas seseorang dapat tumbuh dari apa yang dialami secara langsung yang berkembang kemudian menjadi suatu kebiasaan (Komariah, 2011)

Fakta di lapangan ternyata menggambarkan bahwa terdapat banyak perubahan terkait implementasi pembelajaran dengan mengintegrasikan pendidikan karakter. Hal ini dilatarbelakangi oleh terjadinya krisis karakter dan akhlak generasi muda di sekolah (Wulandari, et al., 2018). Oleh karena itu, pengembangan diri pe- serta didik hendaknya harus dimulai sejak dini terutama saat di sekolah dasar (SD). Pada masa SD peserta didik mulai mengenal teman sebaya, peserta didik mulai menjalin pertemanan secara berkelompok, mempunyai rasa ingin tahu dan rasa penasaran yang tinggi terhadap lingkungan sekitarnya. Pada tingkat SD pendidikan karakter menjadi fondasi utama untuk menentukan kualitas peserta didik dikemudian hari. Hal ini didasarkan pada usia keemasan peserta didik yang mampu menerima kebaikan dan keburukan yang ia pelajari di lingkungan sekitar kemudian akan selalu diingat sampai ia dewasa.

Fakta menunjukkan banyak juga fenomena kenakalan yang dilakukan oleh siswa SD yang tidak sesuai dengan karakter seperti mencuri, mencontek, berkelahi, kekerasan sampai dengan berujung tindakan negatif lainnya (Wulandari, et al., 2018). Kesadaran akan pentingnya penanganan dan pencegahan sejak dini dari pendidik selalu mengupayakan nilai-nilai dengan mengutamakan moralitas yang mampu menjadi peran dan jawaban yang paling tepat untuk dilaksanakan, yaitu dengan pendidikan karakter.

Pendidikan karakter merupakan usaha untuk membantu mempersiapkan generasi bangsa dan siap menghadapi masa depan. Pendidikan karakter dipupayakan sejak SD dengan tujuan (1) menanamkan jiwa kepemimpinan dan tanggung jawab; (2) mengembangkan peserta didik menjadi manusia yang mandiri, kreatif, dan berwawasan kebangsaan; dan (3) mengembangkan lingkungan sekolah sebagai lingkungan belajar yang jujur, amanah serta penuh dengan kreativitas (Salahudin \& Alkrienciehie, 2013, pp. 109-110). Jadi, dapat disimpulkan bahwa pendikan karakter bertujuan untuk membentuk manusia muda menjadi pribadi yang berakhlak mulia. 
Pendidikan karakter di sekolah bukan sekedar mengajarkan mana yang salah dan benar, tetapi lebih dari itu untuk menanamkan kebiasan-kebiasaan yang baik dalam bersikap yang didasarkan oleh nilainilai yang baik juga. Hal ini sejalan dengan pengetahuan yang baik, perasaan yang baik dan perilaku yang baik sehingga mampu terwujudnya kesatuan perilaku dan hidup peserta didik (Nasional, 2011; Samani \& Hariyanto, 2012). Sekolah menjadi berperan penting dalam mengembangkan nilai karakter karena, sekolah menjadi rumah kedua bagi peserta didik (Berkowitz \& Fekula, 1999).

Dunia saat ini sedang mengalami pandemiCOVID-19yang memberikan dampak pada banyak bidang termasuk pendidikan. Dampaknya, dalam bidang pendidikan, yakni pembelajaran tidak dapat dilakukan di sekolah melainkan di rumah, agar penyebaran virus COVID-19 dapat dihambat. Kebijakan yang diambil oleh banyak negara, termasuk Indonesia, membuat pemerintah harus menyediakan alternatif bagi peserta didik yang tidak dapat melaksakanakan proses pendidikan di sekolah. Kebijakan tersebut harus diambil oleh semua pihak (Sudrajat et al., 2021). Sekolah dasar menjadi salah satu jenjang pendidikan yang ikut terkena dampaknya. Sekolah dan guru harus berinovasi mengubah pola pembelajaran tatap muka menjadi pembelajaran tanpa tatap muka. Salah satunya dengan model pembelajaran dalam jaringan (daring) yang direkomendasikan oleh Kemdikbud (Zhafira et al., 2020). Metode ini tidak menuntut siswa hadir di kelas melainkan sepenuhnya melalui pembelajaran jarak jauh dengan memanfaatkan jaringan internet.

Pembelajaran daring disebut sebagai pembelajaran dalam jaringan guna menjangkau kelompok target yang masif dan luas, sehingga pembelajaran dapat dilakukan di mana saja serta diikuti secara gratis atau berbayar (Bilfaqih \& Qomarudin, 2015). Kewajiban dalam melaksanakan kebijakan untuk belajar dari rumah telah menyebabkan pergesaran paradigma pendidikan, yakni telah terjadinya disrupsi teknologi sebagai pergeseran dari pembelajaran tatap muka menjadi tanpa tatap muka. Hal ini juga berdampak bagi peserta didik di SD, baik sisi positif mupun negatif. Banyak kesempatan bagi peserta didik untuk bermain dan enggan untuk belajar sebagaimana mestinya ia lakukan di sekolah. Dampaknya yaitu menurunnya motivasi dan prestasi peserta didik dalam pembelajaran. Selanjutnya, pembelajaran daring berdampak pula pada orang tua. Orang tua menjadi pemeran utama sekaligus menjadi guru bagi anaknya selama proses pembelajaran daring. Dalam hal ini tanggung jawab orang tua dalam pembelajaran anak sangat berpengaruh bagi keberhasilan peserta didik termasuk terhadap pendidikan karakter peserta didik tersebut. Namun, faktanya bahwa banyak orang tua peserta didik tidak mampu sepenuhnya melakukan pendidikan karakter terhadap anaknya tanpa bantuan guru di sekolah (Dewi, 2020). Hal itu tentu bisa berdampak pada menurunnya pendidikan karakter peserta didik jika orang tua tidak dapat mempertahankan pendidikan karakter secara terusmenerus.

Program penguatan pendidikan karakter (PPK) diawali dengan dikeluarkannya Peraturan Presiden Republik Indonesia Nomor 87 Tahun 2017 tentang Penguatan Pendidikan Karakter yang merupakan gerakan pendidikan di bawah tanggung jawab satuan pendidikan untuk memperkuat karakter peserta didik melalui harmonisasi olah hati, olah rasa, olah pikir, dan olah raga. PPK termuat dalam kurikulum K-13. 
Kurikulum sebagai serangkaian proses pembelajaran yang terdiri atas perencanaan dan pelaksanaan kegiatan pembelajaran di sekolah (Fauziah, 2011). Permendikbud Nomor 20 Tahun 2018 tentang Penguatan Pendidikan Karakter pada Satuan Pendidikan Formal juga menjelaskan bahwa PPK pendidikan gerakan pendidikan di bawah tanggung jawab satuan pendidikan untuk memperkuat karakter peserta didik melalui harmonisasi olah hati dan olah rasa. PPK yang merupakan gerakan pendidikan di sekolah guna memperkuat karakter siswa memerlukan dukungan kerja sama antara sekolah, keluarga, dan masyarakat. Nilainilai dalam PPK ditanamkan serta dipraktikkan melalui sistem sekolah agar diketahui, dipahami, dan diterapkan di seluruh sendi-sendi pendidikan. Sekolah sebagai lembaga pendidikan memiliki tanggung jawab untuk membentuk peserta didik yang berkarakter.

PPK dinilai sebagai respons dari sejumlah kelemahan dari pelaksanaan akhlak dan budi pekerti yang didasarkan pada mata pelajaran agama dan kewarganegaraan, sehingga dilakukan inovasi dalam bentuk PPK. Hal itu terkonsep dan terintegrasi dalam semua mata pelajaran, memadukan, memasukan, dan menerapkan nilai-nilai yang diyakini baik dan benar dalam rangka membentuk dan membina keperibadian anak sesuai jati diri (Zakiyah \& Rusdiana, 2014). Melalui PPK diharapkan anak-anak mampu mandiri meningkatkan pengetahuannya, mengkaji, menginternalisasi, dan mempersonalisasi nilai-nilai karakter serta akhlak sehingga terwujud perilaku/kebiasaan sehari-hari anak. Penguatan dan pengembangan mempunyai makna bahwa pendidikan dalam lingkungan sekolah bukanlah sekedar pengetahuan yang ditransfer kepada anak, tetapi sebuah proses yang membawa anak guna memhami dan me- refleksi nilai yang penting dan diwujudkan dalam kehidupan sehari-hari. Di sinilah peran PPK dalam proses pendidikan yaitu untuk membentuk butiran berlian supaya bisa tertanam dalam diri setiap siswa. Pembentukan karakter dalam diri tersebut harus ditanamkan sejak masih usia dini, karena jika nilai-nilai luhur sudah terbentuk dalam diri siswa sejak dini maka ketika dewasa akan menjadi manusia yang berakhlak dan bermoral baik.

Program penguatan karakter dalam proses pembelajaran jarak jauh (daring) harus tetap dikontrol dan diawasi oleh sekolah. Hal itu karena pendidikan karakter harus dijalankan dengan 3K yakni konsisten, kontinu, dan konsekuen, sebagai upaya sadar dan terencana guna menumbuhkan serta mengembangkan karakter peserta didik yang lebih baik (Asrori, 2016). Pendidikan karakter menjadi tanggung jawab bersama guna mewujudkan pembangunan pendidikan nasional yang didasarkan pada membangun manusia Indonesia seutuhnya.

Berdasarkan pernyataan di atas, peneliti tertarik meneliti program pendidikan karakter yang ada di sekolah dasar pada masa daring. Penelitian ini penting dilakukan untuk mendeskripsikan dan menganalisis program PPK yang dilakukan oleh sekolah dasar sehingga nantinya akan menjadi bahan evaluasi bersama dalam menumbuhkan PPK yang lebih maju walaupun di masa pandemi Covid-19. Fokus penelitian ini, yaitu upaya sekolah dalam implementasi program penguatan pendidikan karakter disiplin dan tanggung jawab di Sekolah Dasar Muhammadiyah Ngabean I selama masa pembelajaran daring dan hambatan-hambatan yang dialaminya. 


\section{METODE}

Penelitian ini menggunakan jenis penelitian deskriptif kualitatif dengan desain penelitian studi kasus. Penelitian dilaksanakan di SD Muhammadiyah Ngabean I di Sleman, Yogyakarta. Pengumpulan data pada penelitin ini dilakukan dengan teknik observasi, wawancara, dan dokumentasi. Subjek yang diteliti yaitu kepala sekolah dan guru kelas. Teknik pengumpulan data yang digunakan adalah observasi, wawancara, dan studi dokumen. Observasi dilakukan untuk mengamati penguatan pendidikan karakter sekolah dasar di masa pandemi. Teknik wawancara digunakan untuk memperoleh informasi secara langsung dari sumber yang berkaitan dengan penguatan pendidikan karakter sekolah dasar di masa pandemi Covid 19. Instrumen penelitian berupa item-item pertanyaan dan pedoman wawancara. Untuk mendapatkan validitas logis, peneliti membuat kisi-kisi. Studi dokumen dalam penelitian ini digunakan untuk memperoleh data mengenai penguatan pendidikan karakter di masa pandemi yang berupa dokumen silabus dan rencana pelaksanaan pembelajaran (RPP).

Data yang dikumpulkan dalam penelitian ini yakni berupa data kualitatif. Penyajian data kualitatif dengan menguraikan realita dan menjelaskan sebuah fenomena sosial yang terjadi dari sudut pandang informan (Baez, 2002; Flick, 2012; Flick et al., 2004; Maykut, Pamela \& Richard, 1994). Dalam hal ini penyajian hasil penelitian disajikan dengan cara mendeskripsikan dan menganalisis data yang diperoleh dari wawancara individu, dipadukan dari hasil observasi dan studi dokumen, serta disajikan dalam deskripsi yang sistematis dan logis.
HASIL DAN PEMBAHASAN

Upaya Sekolah dalam Implementasi Penguatan Pendidikan Karakter Tanggung Jawab

Berbagai upaya telah dilakukan sekolah untuk mengimplementasikan penguatan pendidikan karakter di masa pandemi Covid-19, dimulai dari tahap persiapan, pelaksanaan, dan evaluasinya.

\section{Tahap Persiapan Sekolah untuk Me- laksanakan PPK}

PPK di masa pandemi Covid-19 juga harus membuat perencanaan, pelaksanaan, pengawasan, dan evaluasi. Tahapan perencanaan memuat persiapan dalam menanamkan pendidikan karakter di masa pandemi Covid-19 yaitu rencana sekolah dan menyusun dokumen. Pelaksanaan memuat kegiatan-kegiatan yang harus dilakukan siswa di masa pandemi Covid-19, di antaranya dengan mendata dokumen yang dibuat, mengintegrasikan dalam mata pelajaran, dan mengintegrasikan dalam pengembangan diri. Pengawasan memuat kegiatan berupa penetapan standar dan performan pelaksanaan. Evaluasi memuat kegiatan berupa menganalisis data lapangan, memberikan penilaian, dan menentukan tingkat keberhasilan.

Berdasarkan wawancara dengan kepala sekolah di SD Muhammadiyah Ngabean 1 diperoleh data bahwa sekolah tetap memberikan penguatan pendidikan karakter, meskipun berbentuk daring melalui grup WhatsApp (WA). Selain itu, sekolah tetap menekankan aspek karakter siswa melalui himbauan dan motivasi dalam setiap pembelajaran terutama tentang protokol kesehatan di masa pandemi, sekolah juga berperan menjadi sarana untuk menyosialisasikan informasi kesehatan. Hal itu sesuai dengan arahan dan kebijakan Kemendikbud mengenai pembelajaran masa 
pandemi yakni mengutamakan keselamatan dan kesehatan, serta tumbuh kembang dan kondisi psikososial peserta didik (Makarim, 2020).

Sekolah memiliki peran untuk mendidik para siswa mengubah perilaku, yakni perilaku yang tampak dan mempengaruhi bagaimana perilaku itu terjadi, sesuai dengan PPK. Hal ini dilakukan dengan cara himbauan terhadap penerapan protokol kesehatan, seperti mencuci tangan sesering mungkin, menggunakan masker, dan menjaga jarak aman kepada satu sama lain. Cara-cara ini merupakan adaptasi kebiasaan baru yang harus diterapkan dengan disiplin tinggi agar siswa tetap sehat dan mampu melewati pandemi Covid-19, sehingga nantinya adaptasi kebiasaan baru menjadi sebuah keterbiasaan yang baik untuk siswa serta lingkungan di masa yang akan datang.

\section{Tahap Pelaksanaan PPK Tanggung Ja- wab}

Upaya sekolah untuk memperkuat karakter tanggung jawab adalah melalui gerakan penguatan pendidikan karakter yang sudah terprogram dengan baik di kelas masing-masing. Walaupun demikian, untuk hasil yang lebih baik selama pembelajaran daring diupayakan keterlibatan yang lebih besar lagi dari kepala sekolah, guru, dan orang tua. Sekolah berkerja sama dengan orang tua untuk menekankan pendidikan karakter siswa dalam pendampingan pembelajaran selama di rumah. Selain itu, guru selalu menyampaikan PPK yang terintegrasi selama pembelajaran jarak jauh (daring) berlangsung sesuai dengan Surat Edaran Menteri Pendidikan dan Kebudayaan Nomor 4 Tahun 2020 tentang Pelaksanaan Kebijakan Pendidikan dalam Masa Darurat Penyebaran Covid-19.
Dalam proses belajar-mengajar, guru mempunyai tugas untuk mendorong, membimbing, dan memberi fasilitas belajar bagi siswa guna mencapai tujuan yang diinginkannya. Belajar dari rumah dapat difokuskan pada pendidikan kecakapan hidup antara lain mengenai cara hidup di masa pandemi Covid-19. Dalam hal ini guru menyiapkan materi metode pembelajaran serta hal-hal yang berkaitan dengan pembelajaran yang akan berlangsung melalui pembelajaran daring, sedangkan orang tua mendampingi serta ikut menyiapkan segala fasilitas yang dibutuhkan anak dalam proses pembelajaran daring. Inilah momentum yang baik bagi semua pihak, baik guru dan orang tua, untuk mengembangkan pendidikan karakter anak.

Siswa dilatih untuk bertanggung jawab dengan cara mengerjakan tugas-tugas dari guru yang telah disiapkan untuknya. Pada tugas-tugas tersebut dipantau ketepatan waktu pengirimannya dan dinilai hasilnya sehingga peserta didik mendapat balikan mengenai prestasi dan karakter mereka.

Saat ini 24 jam anak berada di rumah, sehingga sangat tepat guru dan orang tua berkolaborasi mendesain pola pendidikan karakter yang baik selama pembelajaran jarak jauh di rumah ini. Peran orang tua di dalam sebuah keluarga adalah sebagai guru, pengajar, penuntun, serta pemimpin dan pemberi contoh bagi anak (Shochib, 2014). Peran orang tua tersebut adalah suatu usaha secara langsung terhadap anak serta peran yang sangat penting dalam menciptakan dan membentuk lingkungan sosial pertama yang akan dijumpai anak. (Mutiah, 2015).

Hal ini berguna untuk mengingatkan para siswa untuk selalu belajar di mana pun ia berada meskipun melalui pembelajaran daring. Dengan demikian, penguat- 
an pendidikan karakter pada siswa juga dilaksanakan secara daring. Adapun setiap pembelajaran yang diberikan kepada siswa walaupun secara daring harus diselipkan tentang penanaman pendidikan karakter dengan mengintegrasikannya disetiap mata pelajaran.

\section{Karakter PPK di Era Pandemi}

SD Muhammadiyah Ngabean 1 memfokuskan PPK yakni disiplin dalam mengumpulkan tugas, dan bertanggung jawab dalam mengerjakan tugas masingmasing yang diberikan oleh guru. Selama kegiatan pembelajaran di rumah, orang tua siswa menyatakan bahwa anaknya dibiasakan mengejarkan hal-hal sederhana untuk disiplin terutama dalam mengerjakan tugas dan mengumpulkannya tepat pada waktunya. Peran orang tua di rumah sangat penting untuk memantau sikap disiplin siswa. Peran orang tua yang pertama adalah mengenalkan dan menanamkan karakter disiplin dan tanggung jawab dengan memberi jadwal waktu belajar di rumah, orang tua membiasakan anak belajar sesuai jadwal yang sudah dibuat, dan orang tua selalu mendampingi, mengawasi, memonitoring kemudian melaporkan kegiatan belajar anak di rumah. Peran orang tua dalam menerapkan perilaku disiplin anak masuk kategori lemah jika tidak dibarengi dengan peran guru di sekolah. Jika peran guru meningkat, maka akan terjadi peningkatan perilaku disiplin anak, begitupun sebaliknya. Dengan demikian, penelitian tersebut menyimpulkan pembentukan karakter anak dipengaruhi oleh guru dan orang tua (Martsiswati \& Suryono, 2014)

Selain karakter disiplin, karakter tanggung jawab yang merupakan kewajiban seseorang untuk melakukan dan menyelesaikan tugas yang dimiliki, menyelesaikan tugasnya secara tuntas dan maksimal lalu berani menanggung apa yang sudah dikerjakan (Syafitri, 2017). Tanggung jawab juga terlihat dalam sikap atau perilaku untuk melakukan tugas dan kewajibannya berdasarkan nilai-nilai yang ada mampu menanggung resiko yang dihadapinya. Di sisi lain diharapkan siswa dapat menjalankan fungsi dari tanggung jawab yakni berani mengambil resiko kegagalan, dapat menjadi siswa yang memiliki kreativitas dan mandiri serta dapat memiliki kepekaan masalah yang tinggi, sehingga mampu menyelesaikan tugas yang diberikan (Suyadi, 2013).

Sikap disiplin dan tanggung jawab yang dilakukan oleh siswa sangat bermanfaat tidak hanya untuk pribadi siswa itu sendiri akan tetapi juga berpengaruh pada lingkungan sekitarnya. Apabila siswa sudah terbiasa sebagai siswa disiplin dan tanggung jawab tentu akan mudah dalam mengerjakan segala sesuatu baik kegiatan, tugas di sekolah, maupun di luar sekolah. Siswa yang memiliki karakter disiplin bisa melaksanakan tanggung jawabnya dengan mudah dan dapat menyelesaikannya dengan tepat waktu dalam mengumpulkan tugas kepada guru.

\section{Hambatan Utama}

Pandemi covid-19 menuntut para guru dan siswa untuk melaksanakan pembelajaran daring sehingga siswa tidak dapat langsung didampingi guru melainkan oleh orang tuanya. Dengan demikian, siswa dituntut untuk mandiri dan jujur dalam mengerjakan tugas yang diberikan oleh guru serta mengumpulkan tugas dengan tepat waktu. Faktor kejujuran dan mandiri siswa dalam mengerjakan tugas menjadi hambatan yang utama. Hal ini dikuatkan dengan hasil survei Kim, Amanda, \& Kathleen (2011) yang menemukan pembelajaran daring dapat meningkatkan potensi men- 
contek lebih besar. Hasil itu menjadi sebuah pekerjaan rumah yang besar bagi orang tua untuk selalu memastikan bahwa anaknya tidak perlu mencontek atau dibantu dalam mengerjakan tugas, agar terdorong karakter tanggung jawab dan mandiri dimulai sejak dini.

Penguatan pendidikan karakter kepada siswa di masa pandemi Covid-19 cukup berbeda dengan penerapan karakter sebelum adanya pandemi Covid-19, karena dalam pembelajaran tatap muka guru dapat mengamati secara langsung bagaimana siswa dalam menerapkan karakter dan guru dapat memberikan contoh atau perilaku secara langsung kepada siswa. Namun, di masa pandemi Covid-19 seperti saat ini guru mengalami kendala dalam pelaksanaan memantau secara langsung penerapan karakter yang dilakukan oleh siswa, karena guru hanya dapat memantau siswa secara daring dengan bukti berupa foto dan video.

Sekolah tetap menekankan aspek karakter siswa melalui himbauan dan motivasi dalam setiap pembelajaran terutama tentang protokol kesehatan di masa pandemi. Sekolah juga berperan menjadi sarana untuk menyosialisasikan informasi kesehatan. Sekolah tetap mengupayakan praktik pendidik karakter walaupun ada hambatan-hambatan yang dihadapi. Dalam masa pandemi seperti ini dapat dikatakan sebagai masa darurat sehingga kebijakan pemerintah untuk menerapkan pembelajaran daring menjadi langkah tepat untuk mewujudkan tujuan pendidikan, walaupun dalam batas yang sangat minimal. Hal itu sesuai dengan arahan dan kebijakan Kemdikbud mengenai pembelajaran masa pandemi, yakni mengutamakan keselamatan dan kesehatan, serta tumbuh kembang dan kondisi psikososial peserta didik (Makarim, 2020).
Sebagai sekolah berbasis agama Islam, SD Muhammadiyah Ngabean I telah berhasil menginternalisasikan nilai-nilai karakter religius di samping nilai tanggung jawab dan kedisiplinan. Ketiga nilai ini adalah bagian integral dari lima nilai dalam Peraturan Presiden Nomor 87 Tahun 2017 tentang Penguatan Pendidikan Karakter, yaitu religiusitas, nasionalisme, kemandirian, gotong-royong, dan integritas. Kelima nilai ini adalah penjabaran dari Pancasila.

Upaya yang cukup strategis untuk membantu penanggulangan krisis nilainilai karakter telah ditempuh dengan berbagai strategi dimulai dari perencanaan, pelaksanaan, sampai evaluasinya. Selama masa pandemi, perlu ada perubahan paradigma dalam proses pembelajaran antara lain pembelajaran berbasis pendidikan karakter melalui daring. Sekolah tetap menjadi pondasi utama yang vital dalam rangka penguatan pendidikan karakter. Sekolah tetap mengupayakan pendidikn karakter tanggung jawab dan disiplin di dalam kegiatan pembelajaran, maupun dalam penerapan protokol kesehatan sesuai standar Covid-19 sehingga siswa dapat mengetahui, merasakan, dan mempraktikkan nilai tanggung jawab dalam dirinya. Upaya ini sejalan dengan pernyataan Rukiyati et al. (2014) bahwa pendidikan karakter yang diformalkan juga memberikan jalan bagi publik yang terikat dengan sekolah dan masyarakat yang lebih luas untuk bersama-sama mengembangkan pemahaman bersama akan nilai-nilai yang diinginkan untuk semua anak.

\section{SIMPULAN}

Berdasarkan hasil penelitian dapat disimpulkan bahwa penguatan pendidikan karakter (PPK) sekolah dasar pada era pandemi Covid-19 sekolah dapat dilakukan dengan cara peran sekolah memberikan 
himbauan penerapan protokol kesehatan seperti mencuci tangan sesering mungkin, menggunakan masker, dan menjaga jarak aman kepada satu sama lain. Sekolah juga berkerja sama dengan orang tua untuk menekankan pendidikan karakter siswa dalam pendampingan pembelajaran selama di rumah. SD Muhammadiyah Ngabean 1 memfokuskan PPK yakni disiplin dalam mengumpulkan tugas dan bertanggung jawab dalam mengerjakan tugas masing-masing yang diberikan oleh guru. Sedangkan kendala yang dihadapi yakni faktor kejujuran dan mandiri siswa dalam mengerjakan tugas menjadi hambatan yang utama. Solusi yang ditawarkan dalam penelitian ini yaitu seluruh stakeholder yang terlibat harus mampu menjalankan tugas masingmasing dengan baik dan selalu mengingatkan tugas dan kewajiban siswa sebagai seorang pelajar.

\section{UCAPAN TERIMA KASIH}

Ucapan terima kasih ditujukan kepada Kepala Sekolah SD Muhammadiyah Ngabean 1 yang berlokasi di Sleman, Yogyakarta yang telah memfasilitasi proses pengumpulan data. Ucapan terima kasih juga disampaikan kepada Lembaga Penelitian Universitas Ahmad Dahlan dan Universitas Sebelas Maret yang telah mendukung penelitian ini.

\section{DAFTAR PUSTAKA}

Asrori, M. A. R. (2016). Integrasi nilai-nilai Pancasila dalam pendidikan karakter dan budaya bangsa yang berbasis pada lingkungan sekolah. Jurnal Rontal Keilmuan Pancasila dan Kewarganegaraan, 2(1), 1-11. DOI: https://doi.org/10.29100/ppkn.v2i1.334.

Baez, B. (2002). Confidentiality in qualitative research: reflections on secrets, power and agency. Qualitative Re- search, 2(1), 35-58. DOI: https://doi.org/10.1177/1468794102002001638.

Berkowitz, M. W., \& Fekula, M. J. (1999). Educating for character. About Campus: Enriching the Student Learning Experience. DOI: https://doi.org/10.1177/108648229900400504.

Bilfaqih, Y., \& Qomarudin, M. N. (2015). Esensi pengembangan pembelajaran daring. Yogyakarta: Deepublish.

Dewi, W. A. F. (2020). Dampak COVID-19 terhadap implementasi pembelajaran daring di sekolah dasar. EDUKATIF : Jurnal Ilmu Pendidikan, 2(1), 55-61. DOI: https://doi.org/10.31004/edukatif.v2i1.89.

Fattah, N. (2016). Landasan manajemen pendidikan. Bandung: Remaja Rosdakarya.

Fauziah, Y. N. (2011). Analisis kemampuan guru dalam mengembangkan keterampilan berpikir kreatif siswa sekolah dasar kelas $\mathrm{V}$ pada pembelajaran ilmu pengetahuan alam. Metodik Dedaktik. Edisi Khusus (2), 98-106. Retrieved from http://jurnal.upi.edu/file/11-Yuli_Nurul-EDIT.pdf.

Flick, U. (2012). From an idea to a research question. In Designing Qualitative Research. London: SAGE Publication.

Flick, U., Kardorff, E. Von, \& Steinke, I. (2004). What is qualitative research? An introduction to the field. In $A$ Companion to Qualitative Research. London: SAGE Publication.

Kim, P., Amanda, L., \& Kathleen, M. (2011). The digital revolution and higher education college presidents, 
public differ on value of online learning. The Digital Revolution and Higher Education College Presidents, Public Differ on Value of Online Learning. 202. http:// pewsocialtrends.org/2011/08 /28/the-digital-revolution-and-higher-education/1/.

Komariah, K. St. (2011). Model pendidikan nilai moral bagi para remaja menurut perspektif Islam. Taklim: Jurnal Pendidikan Agama Islam, 9(1), 45-54. http://jurnal.upi.edu/file/04_MODEL_P ENDIDIKAN_NILAI_MORAL-KOKOM.pdf.

Makarim, N.A. (2020). Pelaksanaan kebijakan pendidikan dalam masa darurat penyebaran Corona Virus Disease (Covid-19). In Surat Edaran Permendikbud Nompr 4 Tahun 2020.

Martisiswati, E. \& Suryono, Y. (2014). Peran orang tua dan pendidik dalam menerapkan perilaku disiplin terhadap anak usia dini. Jurnal Pendidikan dan Pemberdayaan Masyarakat, 1(2), 187-198. DOI: https://doi.org/10.21831/jppm.v1i2.2688.

Maykut, P. \& Richard, M. (1994). Beginning qualitative research: A philosphical and practical guide. New York: Routledge.

Mutiah, D. (2015). Faktor-faktor yang mempengaruhi kekerasan terhadap anak. Jakarta: Kencana.

Nasional, K.P. (2011). Panduan pelaksanaan pendidikan karakter. Jakarta: BPPPK Kemdiknas RI.

Nasional, K. P. (2010). Penguatan metodologi pembelajaran berdasarkan nilai-nilai budaya untuk membentuk daya saing dan karakter bangsa. Jakarta: BPPPK Kem- diknas RI.

Peraturan Presiden Republik Indonesia Nomor 87 Tahun 2017 tentang Penguatan Pendidikan Karakter.

Peraturan Menteri Pendidikan dan Kebudayaan Nomor 20 Tahun 2018 tentang Penguatan Pendidikan Karakter pada Satuan Pendidikan Formal.

Rukiyati, Sutarini, N. \& Priyoyuwono (2014). Penanaman nilai karakter tanggung jawab dan kerja sama terintegrasi dalam perkuliahan ilmu pendidikan. Jurnal Pendidikan Karakter, 4(2), 213-224. DOI: https://doi.org/10.21831/jpk.v0i2.2797.

Ruyadi, Y. (2010). Model pendidikan karakter berbasis kearifan budaya lokal (penelitian terhadap masyarakat adat Kampung Benda Kerep Cirebon Provinsi Jawa Barat untuk pengembangan pendidikan karakter di sekolah). Proceedings of The 4th International Conference on Teacher Education; Join Conference UPI \& UPSI. Bandung, Indonesia, 8-10 November 2010.

Salahudin, A. \& Alkrienciehie, I. (2013). Pendidikan Karakter: Pendidikan berbasis agama dan budaya bangsa. Bandung: Pustaka Setia.

Samani, M., \& Hariyanto (2012). Konsep dan model pendidikan karakter. PT. Remaja Rosdakarya.

Shochib, M. (2014). Pola asuh orang tua dalam membantu anak mengembangkan disiplin diri. Jakarta: Rineka Cipta.

Sudrajat, C. J., Agustin, M., Kurniawati, L., \& Karsa, D. (2021). Strategi kepala TK dalam meningkatkan mutu pendidik- 
an pada masa pandemi Covid 19. Jurnal Obsesi: Jurnal Pendidikan Anak Usia Dini, 5(1), 508-520. DOI: https://doi.org/10.31004/obsesi.v5i1.582.

Suyadi, I. (2013). Strategi pembelajaran pendidikan karakter. Bandung: PT Remaja Rosdakarya.

Syafitri, R. (2017). Meningkatkan tanggung jawab belajar melalui strategi giving questions and getting answers pada siswa. Jurnal Penelitian dan Pengembangan Pendidikan, 1(2), 57-63. DOI: http://dx.doi.org/10.23887/jppp.v1i 2.12623 .
Wulandari, E., Taufik, M., \& Kuncahyono, K. (2018). Analisis implementasi full day school sebagai upaya pembentukan karakter siswa di SD Muhammadiyah 4 Kota Malang. Jurnal Pemikiran dan Pengembangan Sekolah Dasar (JP2SD), 6(1), 65-74. https://doi.org/10.22219/jp2sd.v6i1.5904.

Zakiyah, Q. Y., \& Rusdiana, A. (2014). Pendidikan nilai: Kajian teori dan praktik di sekolah. Bandung: Pustaka Setia.

Zhafira, N. H., Ertika, Y., \& Chairiyaton. (2020). Persepsi mahasiswa terhadap perkuliahan daring sebagai sarana pembelajaran selama masa karantina Covid-19. Jurnal Bisnis dan Kajian Strategi Manajemen, 4(1), 37-45. DOI: https://doi.org/10.35308/jbkan.v4i1. 1981 